\title{
Composition and temporal dynamics of planktonic archaeal assemblages from anaerobic sulfurous environments studied by 16S rDNA denaturing gradient gel electrophoresis and sequencing
}

\author{
Emilio O. Casamayor ${ }^{1, *}$, Gerard Muyzer ${ }^{2, * *}$, Carlos Pedrós-Alió $^{1}$ \\ ${ }^{1}$ Departament de Biologia Marina i Oceanografia, Institut de Ciències del Mar, CMIMA-CSIC, \\ Pg. Maritim de la Barceloneta, 08003 Barcelona, Spain \\ ${ }^{2}$ Max Planck Institute for Marine Microbiology, Celsiusstr. 1, 28359 Bremen, Germany
}

\begin{abstract}
The planktonic archaeal assemblages of several anaerobic, sulfide-rich, aquatic environments were analyzed in space and time by PCR-denaturing gradient gel electrophoresis and sequencing of 16S rRNA gene fragments. The systems were sampled in different years between 1992 and 1998. PCR products were obtained directly from the original DNA without previous nested amplification and yielded successful fingerprints with mostly sharp bands in the gel. Nineteen samples from the anaerobic hypolimnia of 8 lakes and 1 coastal lagoon in NE Spain, Mallorca and Switzerland were compared and a temporal survey was carried out in one of the lakes (Lake Vilar). Between 4 and 14 well-defined bands appeared. All the sequenced bands belonged to Archaea. Although most of the water bodies shared the same climatic conditions and presence of sulfide, the limnological parameters were different among them and different fingerprints were observed in different lakes. Euryarchaeota, i.e., methanogen- and thermoplasma-related sequences, appeared in all the samples but crenarchaeota were recovered only from Lake Vilar. A temporal shift in the predominant members of the archaeal assemblage from crenarchaeota to members of the cluster of thermoplasmales and relatives took place in Lake Vilar between February and June. Sequences related to thermoplasmales and crenarchaeota were distantly related to cultured strains $(81 \%$ similarity in $16 \mathrm{~S}$ rDNA) and clustered with branches represented only by environmental clones, whereas sequences related to methanogens grouped with a sequence from an endosymbiont of 1 anaerobic ciliate. A new branch of freshwater euryarchaeota appeared within the cluster of thermoplasmales and relatives. Our study indicates the presence of dynamic archaeal populations in the water column of nonthermophilic, sulfide-rich environments, further extending the diversity and distribution of Archaea in nature. The temporal shift in community composition in Lake Vilar suggests that Archaea grow under in situ conditions. If this is the case, Archaea would be active players in the anaerobic biogeochemical cycles of these environments.
\end{abstract}

KEY WORDS: Archaea · DGGE · Fingerprinting $\cdot$ 16S rDNA · Sulfurous lakes · Diversity

Resale or republication not permitted without written consent of the publisher

\section{INTRODUCTION}

Archaea illustrate better than any other group of organisms how dramatically our perception of the liv-

Present addresses:

*Observatoire Ocèanologique de Banyuls-CNRS, BP 44, 66651 Banyuls-sur-Mer, France. E-mail: emilio@obs-banyuls.fr

${ }^{* *}$ Kluyver Institute of Biotechnology, Delft University of Technology, 2628 BC Delft, The Netherlands ing world has changed since the biosphere has been examined from a molecular point of view (Pace 1997). First, analysis of ribosomal RNA sequences surprisingly revealed that Archaea constitute a third domain of life (Woese et al. 1990, Woese 2000). Second, when molecular studies were carried out with natural samples, Archaea were shown to be ubiquitous (DeLong 1992, Fuhrman et al. 1992, Hershberger et al. 1996 Stein \& Simon 1996). The phenotypic range of cultivated Archaea had restricted these organisms to habi- 
tats with high temperature, extreme values of $\mathrm{pH}$, high salinity or anaerobic environments allowing methanogenesis. Thus, the genetic and metabolic diversity of Archaea and their ecological distribution seemed more limited than those of Bacteria. Uncultured Archaea, however, extend from marine planktonic environments to soils and sediments (see a review in DeLong 1998), showing up also in close association with animals (Preston et al. 1996, Van der Maarel et al. 1998) and bacteria (Boetius et al. 2000). Therefore, the expected metabolic capabilities of Archaea have increased greatly. Recently, a combination of in situ hybridization and microautoradiography has shown that marine Archaea are active and able to take up amino acids (Ouverney \& Fuhrman 2000).

During the last few years, more and more sequences have been deposited in databases and new groups of uncultured Archaea have been described (DeLong 1992, Fuhrman et al. 1992, Barns et al. 1996, Jurgens et al. 1997, 2000, Buckley et al. 1998). These groups are the marine and freshwater sediments cluster (Crump \& Baross 2000), the terrestrial cluster (Buckley et al. 1998) and some cosmopolitan marine clusters (Massana et al. 2000). However, ecological studies covering temporal and spatial variability in the archaeal assemblages are still scarce (DeLong et al. 1994, Massana et al. 1998, 2000, Murray et al. 1998, 1999, Pernthaler et al. 1998, Crump \& Baross 2000, Cytryn et al. 2000, Karner et al. 2001). Such studies provide insight into changes in community structure and population dynamics and yield information useful to investigate their functional roles. In Archaea most of these studies have concentrated on marine and terrestrial samples, in a hypersaline lake or in sediments. Only a handful of studies have been carried out in the water column of freshwater habitats: 2 meromictic lakes (Øvreås et al. 1997, Casamayor et al. 2000b), a high mountain lake (Pernthaler et al. 1998) and a boreal forest lake (Jurgens et al. 2000). Whether Archaea are a common component of freshwater plankton is still uncertain.

In the present work, we have carried out a comparative survey on the composition of the archaeoplankton from several anaerobic sulfurous water bodies and a temporal study centered on one of them. We used denaturing gradient gel electrophoresis (DGGE) fingerprinting of 16S rRNA genes, PCR-amplified directly from the original DNA (Muyzer et al. 1998). This technique allows extensive comparison on a spatio-temporal scale. In addition, bands were excised from the gel and sequenced, and the identity of the populations was investigated. DGGE has been successfully applied to Bacteria but, to our knowledge, direct DGGE analysis of Archaea has been shown in only 1 recent study (Cytryn et al. 2000) besides our own work (Casamayor et al. 2000b). Sequence analysis of the $600 \mathrm{bp} 16 \mathrm{~S}$
rDNA fragments indicated the presence of a new lineage within euryarchaeota. For the first time, we describe temporal changes in the composition of freshwater archaeal assemblages involving a shift between distantly related phylogenetic groups.

\section{MATERIALS AND METHODS}

Environments, sampling and analysis. The systems sampled are located in karstic regions of northeastern Spain (Banyoles and Cuenca), in the coastal area of Mallorca (El Cibollar, Balearic Islands), and in the Swiss Alps (Lake Cadagno) and were sampled in different years between 1992 and 1998. Basins III, IV and VI from Lake Banyoles, Lake Vilar and Lake Cisó are in the Banyoles karstic area $\left(42^{\circ} 8^{\prime} \mathrm{N}, 2^{\circ} 45^{\prime} \mathrm{E}\right)$ and the microbial communities inhabiting these systems have been extensively studied by both conventional (for reviews see Guerrero et al. 1987, Pedrós-Alió \& Guerrero 1993) and molecular methods (Casamayor et al. 2000a,b). Lake Banyoles, covering a surface area of $1.1 \mathrm{~km}^{2}$, is a polje comprising 6 main basins. The 3 basins studied are located in the northern area of the lake. Basins III and IV are meromictic with 25 and $18 \mathrm{~m}$ maximal depth, respectively, and incoming water seeps through bottom springs (Casamitjana \& Roget 1993). The chemocline oscillates between 16 and $21 \mathrm{~m}$ in Basin III and between 12 and $17 \mathrm{~m}$ in Basin IV depending on the season. Basin VI is $17 \mathrm{~m}$ deep and holomictic, with a thermocline situated around 12 to $13 \mathrm{~m}$, and does not have bottom seepage. Blooms of the photosynthetic bacteria Chorobium phaeobacteroides and Thiocystis minor (formerly Chromatium minus) have been described in the 3 basins (Garcia-Gil et al. 1996). Lake Vilar is a meromictic lake formed by 2 basins with a maximum depth of $9 \mathrm{~m}$ and a surface area of $11000 \mathrm{~m}^{2}$, and is connected to Lake Banyoles through a small and shallow channel. High sulfide concentrations are found throughout the year, although sulfide is restricted to the deeper, high-conductivity waters. A stable chemocline exists at $4.5 \mathrm{~m}$, where dense populations of photosynthetic sulfur bacteria develop. Lake Cisó is a small holomictic lake $\left(650 \mathrm{~m}^{2}\right)$, $1 \mathrm{~km}$ away from the former, with a maximum depth of $6.5 \mathrm{~m}$. The thermocline is at $1.5 \mathrm{~m}$, where dense populations of photosynthetic sulfur bacteria develop. The lake becomes anoxic during winter holomixis (complete mixing) and high sulfide concentrations (up to $500 \mu \mathrm{M})$ are present in the entire water column (Pedrós-Alió \& Guerrero 1993). Lake El Tobar and Lake La Cruz belong to the Cuenca karstic system $\left(39^{\circ} 59^{\prime} \mathrm{N}, 1^{\circ} 52^{\prime} \mathrm{W}\right)$. Biological and physico-chemical properties of these lakes have been well described (Miracle et al. 1992 and references therein, Casamayor 
et al. 2000a). Lake El Tobar is meromictic, $19.5 \mathrm{~m}$ in depth, and contains permanently anoxic saline waters (consisting mostly of a sodium chloride brine) starting at about $12 \mathrm{~m}$ depth, where blooms of photosynthetic bacteria develop (Garcia-Gil et al. 1999). Lake La Cruz is a meromictic freshwater lake, $24 \mathrm{~m}$ deep, with bottom waters enriched in calcium, magnesium and iron bicarbonates, and low amounts of sulfide; a thermocline exists at 8 to $12 \mathrm{~m}$ and gas-vacuolate species of photosynthetic bacteria Pelodictyon and Amoebobacter develop there.

El Cibollar is a small coastal lagoon on the northeast of the S'Albufera of Mallorca, $750 \mathrm{~m}$ from Alcudia Bay $\left(39^{\circ} 50^{\prime} \mathrm{N}, 3^{\circ} 10^{\prime} \mathrm{E}\right)$, for which some limnological studies have been carried out (Moyà et al. 1987, Borrego et al. 1997). The lagoon has a surface area of almost 4 ha, and average depth is $3.3 \mathrm{~m}$ and maximal depth $8.7 \mathrm{~m}$. The oxygen-sulfide interface is located at 3 to $4 \mathrm{~m}$ with maximum $\mathrm{H}_{2} \mathrm{~S}$ concentrations up to $2000 \mu \mathrm{M}$. Finally, Lake Cadagno $\left(46^{\circ} 33^{\prime} \mathrm{N}, 8^{\circ} 43^{\prime} \mathrm{E}\right)$ is a permanently stratified, sulfide-rich meromictic lake $\left(\mathrm{H}_{2} \mathrm{~S}\right.$ concentrations around $1000 \mu \mathrm{M})$, located at $1923 \mathrm{~m}$ above sea level in the Piora valley (Southern Switzerland). It is about $850 \mathrm{~m}$ long and $420 \mathrm{~m}$ wide, with a maximum depth of $21 \mathrm{~m}$ and a permanent chemocline found between 9 and $14 \mathrm{~m}$. The lower layer is rich in dissolved salts brought by sulfurous sublacustrine springs. Several biogeochemical and molecular studies have been carried out in this lake (Wagener et al. 1990, Putschew et al.
1996, Schanz et al. 1998, Bosshard et al. 2000, Fritz \& Bachofen 2000, Tonolla et al. 2000), reporting blooms of the purple sulfur bacteria Chromatium okenii and Amoebobacter purpureus at the chemocline.

For most of the samples, depth profiles of water temperature, conductivity and oxygen concentration were measured in situ using a portable multisensor probe (Hydrolab DS-3; Hydrolab Instruments, TX, USA). Sampling depths were selected according to physicochemical parameters. Water samples were taken using a PVC cone connected through tubing to a battery-driven pump as described elsewhere (Miracle et al. 1992). Sulfide was measured with the methylene blue colorimetric method in $10 \mathrm{ml}$ subsamples fixed quickly by addition of $100 \mu \mathrm{l}$ of $10 \mathrm{~N} \mathrm{NaOH}$ and Zn-acetate to a final concentration of $0.1 \mathrm{M}$ (Golterman et al. 1978). Cells were counted in samples fixed with $4 \%$ formaldehyde (v/v) and stained with DAPI (Porter \& Feig 1980) using epifluorescence microscopy. For DNA analysis, plastic containers were filled with 1 to $5 \mathrm{l}$ of water and were kept in the dark on ice until processed in the laboratory a few hours later. Sampling depths for molecular studies are indicated in Table 1. Samples were concentrated using a refrigerated centrifuge at $8000 \times g$ (Sorvall Instruments, DuPont, DE, USA) and cell pellets were kept frozen at $-70^{\circ} \mathrm{C}$ until further use. Microscopic observation of the supernatants showed that only between 1 and $3 \%$ of the cells were not recovered by this method.

Table 1. Temperature, conductivity, sulfide concentration and DAPI counts of prokaryotes (values $\times 10^{6}$ cells $\mathrm{ml}^{-1}$ ) for the depths sampled for molecular analysis. The depth of the oxic-anoxic interface in each lake is also indicated. ND: not determined. *Sample from the oxic-anoxic interface (presence of $1.4 \mathrm{mg} \mathrm{l}^{-1}$ oxygen)

\begin{tabular}{|c|c|c|c|c|c|c|c|c|}
\hline Sample & $\begin{array}{c}\text { Date } \\
\text { (d.mo.yr) }\end{array}$ & $\begin{array}{l}\text { Interface } \\
(\mathrm{m})\end{array}$ & $\begin{array}{l}\text { Depth } \\
\text { (m) }\end{array}$ & $\begin{array}{c}\text { Temperature } \\
\left({ }^{\circ} \mathrm{C}\right)\end{array}$ & $\begin{array}{l}\text { Conductivity } \\
\left(\mu \mathrm{S} \mathrm{cm}^{-2}\right)\end{array}$ & $\mathrm{pH}$ & $\begin{array}{l}\mathrm{H}_{2} \mathrm{~S} \\
(\mu \mathrm{M})\end{array}$ & $\begin{array}{l}\text { Total } \\
\text { cells }\end{array}$ \\
\hline El Cibollar lagoon & 26.05 .98 & 4.0 & 6.00 & 25 & 48000 & $7-8$ & present & ND \\
\hline Lake Cadagno & 02.07 .98 & 11.5 & 13.00 & 8 & 320 & $7-8$ & 1050 & ND \\
\hline Lake La Cruz & 29.09 .94 & 11.8 & 12.25 & 7 & 470 & $7-8$ & 20 & 18.2 \\
\hline Lake El Tobar & 30.09 .94 & 11.5 & 14.00 & 13 & 16120 & $7-8$ & 15 & ND \\
\hline Banyoles B-III & 14.09 .95 & 16.5 & 17.00 & 13 & 1366 & $7-8$ & 6 & ND \\
\hline Banyoles B-IV & 29.09 .95 & 11.5 & 13.25 & 18 & 1870 & $7-8$ & 30 & 21.3 \\
\hline Banyoles B-VI & 29.09 .95 & 12.5 & 14.00 & 16 & 1400 & $7-8$ & 10 & 4.3 \\
\hline Lake Cisó & 25.09 .92 & 1.5 & 1.75 & 16 & 2200 & 7.1 & 400 & 17.3 \\
\hline Lake Cisó & 19.02 .96 & 0.0 & 0.10 & 9 & 2000 & 7.6 & 150 & 19.1 \\
\hline Lake Cisó & 09.04 .96 & 1.5 & 1.75 & 11 & 2280 & 7.1 & 230 & 41.2 \\
\hline Lake Vilar & 30.09 .93 & 4.0 & 4.40 & 16 & 2000 & 7.6 & 819 & 22.6 \\
\hline Lake Vilar & 19.02 .96 & 4.25 & 4.75 & 13 & 2380 & 7.5 & 190 & 8.0 \\
\hline Lake Vilar & 19.02 .96 & 4.25 & 7.00 & 13 & 2370 & 7.5 & 986 & 10.5 \\
\hline Lake Vilar & 09.04 .96 & 3.75 & 4.25 & 13 & 2430 & 7.5 & 720 & 17.5 \\
\hline Lake Vilar & 09.04 .96 & 3.75 & 7.00 & 13 & 2770 & 7.5 & 707 & 15.5 \\
\hline Lake Vilar* & 23.04 .96 & 3.75 & 3.75 & 15 & 1180 & 7.3 & 4 & 8.3 \\
\hline Lake Vilar & 23.04 .96 & 3.75 & 4.25 & 15 & 1660 & 7.6 & 480 & 42.1 \\
\hline Lake Vilar & 23.04 .96 & 3.75 & 7.00 & 14 & 2040 & 7.5 & 837 & 16.3 \\
\hline Lake Vilar & 08.05 .96 & 3.8 & 4.40 & 16 & 1600 & 7.5 & 550 & 28.0 \\
\hline Lake Vilar & 21.05 .96 & 4.0 & 4.40 & 17 & 1910 & 7.5 & 844 & 31.0 \\
\hline Lake Vilar & 20.06 .96 & 4.0 & 6.00 & 16 & 2420 & 7.6 & 800 & 17.2 \\
\hline
\end{tabular}


DNA extraction and analysis. DNA was extracted with hot SDS-phenol and purified with phenol-chloroform-isoamylalcohol (25:24:1 v/v) followed by ethanol precipitation as reported elsewhere (Casamayor et al. $2000 b)$. Fragments of the 16 S rDNA suitable for subsequent DGGE analysis were obtained with the primer combination ARC344F (ACG GGG YGC AGC AGG CGC GA) (Stahl \& Amann 1991) and ARC915R (GTG CTC CCC CGC CAA TTC CT) (Raskin et al. 1994). A 40 nucleotide GC-rich sequence was attached to the $5^{\prime}$ end of the forward primer according to Muyzer et al. (1998). Annealing temperature was $61^{\circ} \mathrm{C}$. PCR conditions and DGGE were as described before (Casamayor et al. 2000b), running for $3.5 \mathrm{~h}$ at a constant voltage of $200 \mathrm{~V}$ and at $60^{\circ} \mathrm{C}$ in a 20 to $80 \%$ vertical denaturant gradient (100\% denaturant agent is $7 \mathrm{M}$ urea and $40 \%$ deionized formamide). After electrophoresis, the gels were stained with ethidium bromide and photographed with UV transillumination (314 nm) with a Polaroid camera. The photographs were scanned, and the digitized images were processed with the NIH Image software (National Institutes of Health, Bethesda, $\mathrm{MD}, \mathrm{USA}$ ) to measure relative band intensities. A DGGE band was defined as an ethidium bromide signal higher than $0.2 \%$ of the total intensity of all bands in each lane. The variability in intensities measured among replicate analyses was less than $4 \%$. Prominent bands were excised from the gels and sequenced as reported elsewhere (Casamayor et al. 2000b).

Sequences were submitted to basic local alignment search (Altschul et al. 1990) to get a first indication of what sequences were retrieved. Then, sequences were aligned by using the ARB program package (Technical University of Munich, Munich, Germany; http://www. arb-home.de). Partial sequences were inserted into the optimized and validated tree available in ARB (derived from complete sequence data), by using the maximumparsimony criterion and a special ARB parsimony tool that did not affect the initial tree topology. Nucleotide sequence accession numbers at EMBL are as follows: AJ239988 to AJ239990 (CIARC-1 to CIARC-3), AJ240004 to AJ240006 (VIARC-1 to VIARC-3), AJ306414 (VIARC-0), AJ306415 (VIARC-4), AJ306416 (VIARC-5), AJ306409 (CIBARC-1), AJ306410 (TOARC2), AJ306411 (CRARC-3), AJ306412 (CRARC-4) and AJ306413 (BANARC-5 to BANARC-7).

\section{RESULTS}

All systems studied had 2 water layers separated according to gradients of temperature or conductivity. The top water layer (epilimnion) was oxygenated and with light. The bottom water layer (hypolimnion) was anoxic, sulfide was present, and it was in the dark.
Very little archaeal PCR product (or no product at all) was obtained from the upper aerobic layers. Even at the oxic-anoxic interface most of the DGGE bands found in the hypolimnia were absent. Thus, we focused all the analyses in the anoxic hypolimnia. Different sulfide concentrations were measured for the hypolimnion of each system, ranging from $6 \mu \mathrm{M}$ in Basin III of Lake Banyoles to $1050 \mu \mathrm{M}$ in Lake Cadagno (Table 1). Temperature in the study sites ranged between 7 and $25^{\circ} \mathrm{C}$. Conductivity ranged between 1600 and $48000 \mu \mathrm{S} \mathrm{cm}^{-2}$ and $\mathrm{pH}$ was between 7 and 8 . Most systems were sampled in summer (July to September), whereas Lake Cisó and Lake Vilar were sampled several times and in different seasons. The concentration of prokaryotes in the bottom waters was around $10^{7}$ cells $\mathrm{ml}^{-1}$ (Table 1 ). This count includes all DAPI-stained particles with a prokaryote-like morphology. Morphologically conspicuous cells such as green and purple photosynthetic sulfur bacteria (Chlorobium sp. and Thiocystis minor, respectively) were counted separately (see results in Casamayor et al. 2000a).

Lake Vilar was sampled twice each month, from February to June 1996. No marked differences in conductivity, temperature or $\mathrm{pH}$ were found during the survey in the hypolimnion of the lake (Table 1). Sulfide concentrations, however, increased from winter to summer in the hypolimnion (from 800 to $1200 \mu \mathrm{M}$ at around $4.5 \mathrm{~m}$ ). Lake Cisó was sampled at the end of summer 1992 and in winter and early spring 1996. Small differences were found in the physicochemical parameters measured in this lake, and sulfide ranged between 150 and $400 \mu \mathrm{M}$ (Table 1). Lake Cisó becomes

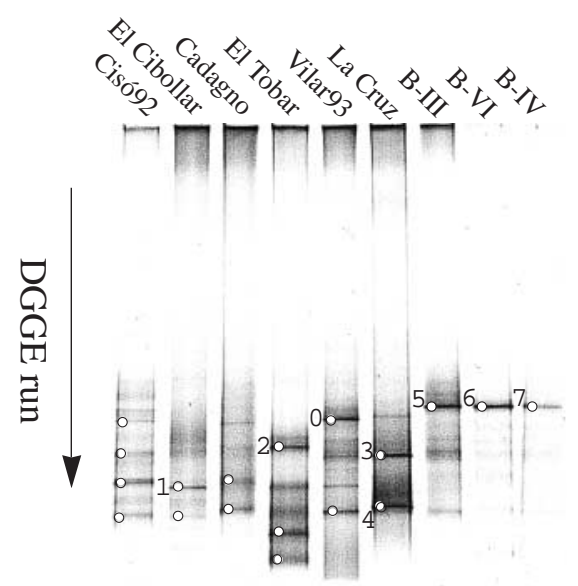

Fig. 1. Negative image of the ethidium bromide-stained denaturing gradient gel electrophoresis (DGGE) gel containing the archaeal 16S rDNA fragments from the different environments. Bands that were cut off from the gel are labeled but only those that yielded a clean sequence have a number. 92 and 93 samples were taken in 1992 and 1993, respectively 

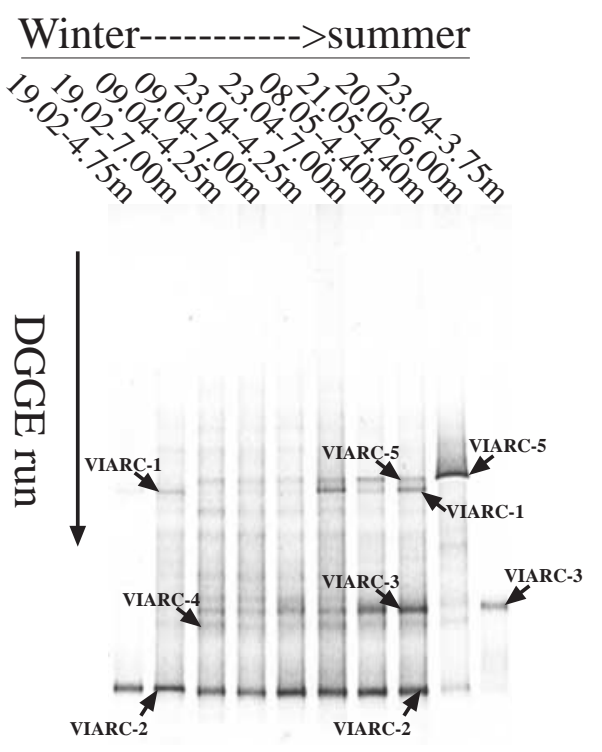

Fig. 2. Negative image of the ethidium bromide-stained DGGE gel containing the archaeal 16S rDNA fragments from the temporal survey in Lake Vilar. The same sequence was recovered when bands with identical position in the gel and from different dates were analyzed

anoxic during winter holomixis because of its special limnological conditions, and sulfide concentrations up to $400 \mu \mathrm{M}$ were measured from the bottom of the lake to the surface.

Anaerobic archaeal assemblages inhabiting these systems were compared by DGGE fingerprinting. The number of well-defined sharp bands ranged between 4 and 14 among lakes (Fig. 1), and in most cases just a few bands (1 to 3) appeared as the most intense. The fingerprints showed differences in the mobility of the DGGE bands among hypolimnia of lakes (Fig. 1). Very similar fingerprints were observed in winter and in spring for Lake Vilar (Fig. 2) and Lake Cisó (see Fig. 3 in Casamayor et al. 2000b). In Lake Vilar, however, a shift was apparent in summer from the rest of the year (lane for 20 June in Fig. 2). Very little archaeal PCR product was obtained from the upper aerobic layers of Lake Vilar. As was the case with other lakes, most of the archaeal DGGE bands appearing in the hypolimnetic samples were absent from the oxic-anoxic interface. As an example of the DGGE band pattern from such an interface, the $3.75 \mathrm{~m}$ sample is presented in Table 1 and in the last lane in Fig. 2.

The most prominent bands in the profiles (in terms of intensity and frequency of appearance) were excised, re-amplified, puri- fied and sequenced (27 bands). From these, only 17 bands yielded good-quality sequences. Some of them were obtained from the same position in different lanes and gave the same sequence (e.g., VIARC-2 in Fig. 2). Thirteen sequences were included in a phylogenetic tree (Fig. 3) together with bands previously obtained from Lake Cisó in 1996 (CIARC-1, -2 and -3; Casamayor et al. 2000b). The sequences were named, in addition to the number shown in Figs $1 \& 2$, with a code for the lake and a code for the primer used (ARC). The components of the archaeal assemblages were distributed among 3 groups: methanogens, thermoplasmales and crenarchaeota (Fig. 3). Sequences from thermoplasmales and relatives cluster and crenarchaeota were very distantly related to cultured organisms (e.g., 81\% to Desulfurococcus mobilis or Thermoplasma acidophilum) whereas methanogens where more similar to cultured strains (e.g., $90 \%$ to Methanospirillum hungatei). The sequences belong-

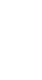
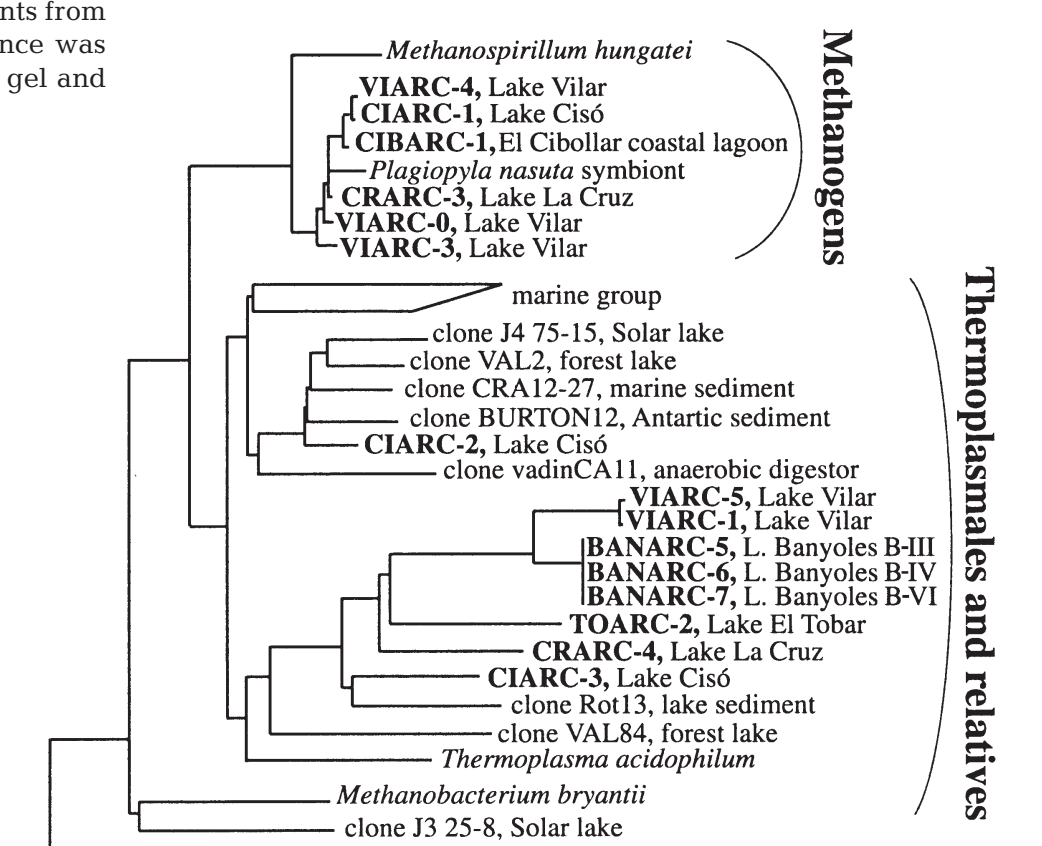


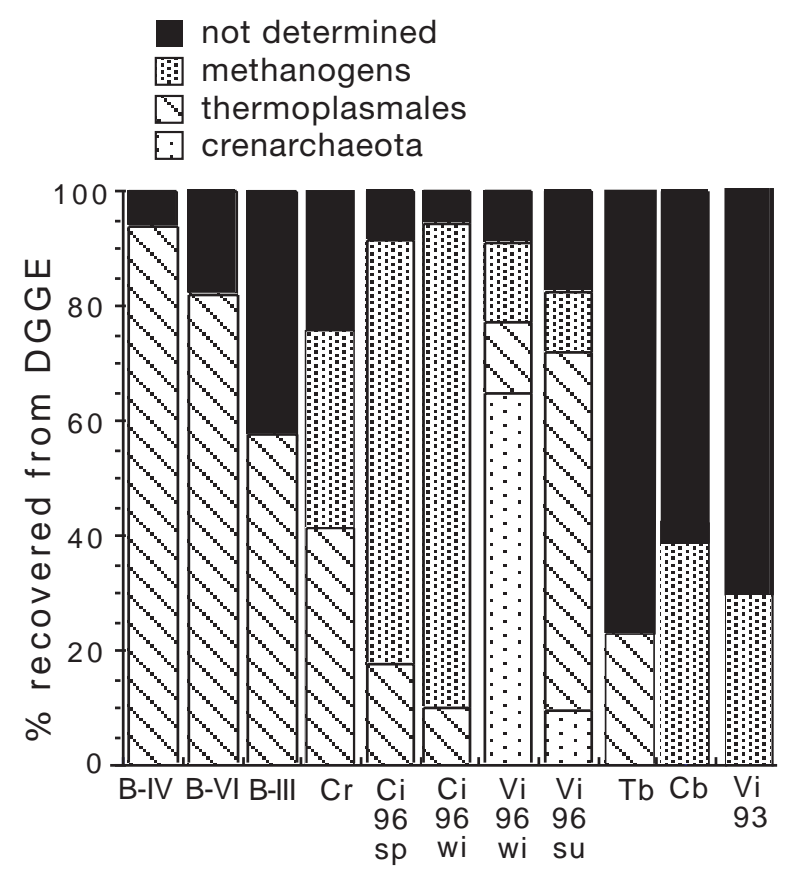

Fig. 4. Relative abundance of archaeal groups in the different lakes. Quantitative data were obtained from band intensities in the gels in Figs $1 \& 2$, and from a previous study in Lake Cisó (Casamayor et al. 2000b). Samples: basins from Lake Banyoles (B-III, B-IV and B-VI); Lake Vilar in summer (Vi96su) and in winter (Vi96wi) 1996 and September 1993 (Vi93); Lake Cisó in spring (Ci96sp) and winter (Ci96wi); Lake La Cruz (Cr); Lake El Tobar (Tb); and El Cibollar coastal lagoon (Cb)

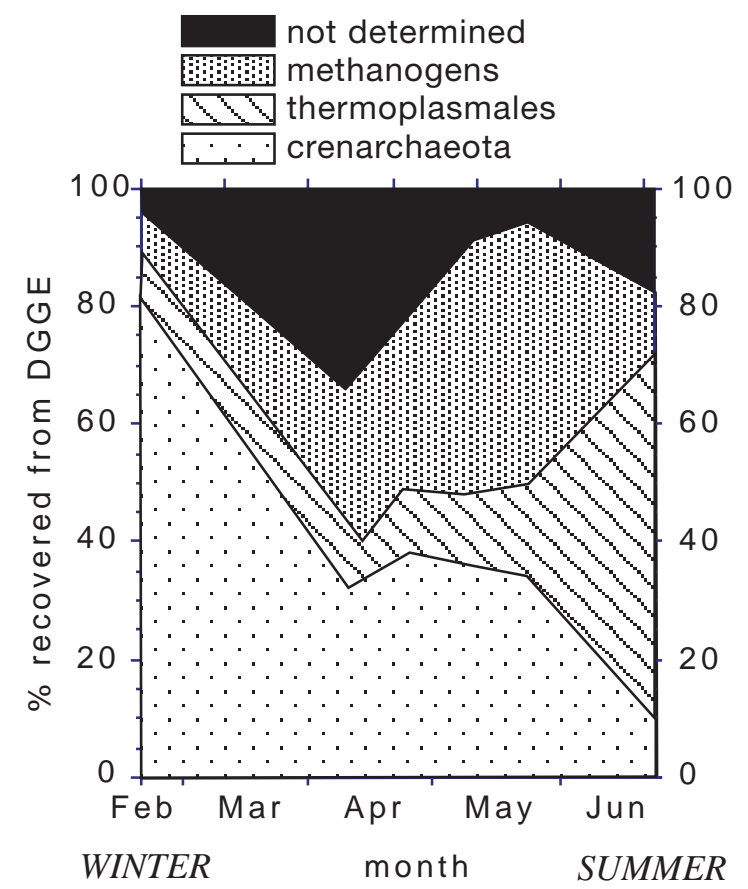

Fig. 5. Survey of the relative abundance of different archaeal groups along the temporal study in Lake Vilar. Quantitative data were obtained from the gel in Fig. 2 ing to methanogens formed a closely related group and were all related to endosymbionts of anaerobic ciliates (97\% similarity). Thermoplasmales-related sequences obtained from different lakes grouped in a single branch that was not related to previously described sequences. Lake Vilar was the only water mass where a planktonic crenarchaeota-like population was detected.

The relative band intensities were used as an estimate of abundance to compare the composition of the archaeal assemblages among samples that were amplified in the same PCR run. For this comparison, the sequences were pooled into 3 phylogenetic groups: methanogens, thermoplasmales-related and crenarchaeota. An average of $22 \%$ of the total band intensity in each lane could not be sequenced and assigned to known organisms and, therefore, these bands were assigned to an 'unidentified' class (black bars in Figs 4 $\& 5)$. In general, this fraction consisted of minor components of the community (i.e., weak bands). It must be kept in mind that these bands may correspond to any of the 3 identified groups or to other groups of Archaea. On the basis of these results, we found environments where thermoplasmales-related organisms reached $>50 \%$ of the total intensity (Lake Vilar in summer and the 3 basins of Lake Banyoles), environments where methanogens reached $>50 \%$ of the total intensity (Lake Cisó) and environments dominated by 1 crenarchaeota (Lake Vilar in winter). In Lake La Cruz $40 \%$ was assigned to thermoplasmales-related organisms and $35 \%$ to methanogens. In El Cibollar coastal lagoon, methanogens were $40 \%$ but the composition of the remaining $60 \%$ was not possible to allocate. Lake El Tobar had a very high unidentified fraction too and thermoplasmales-related organisms were found at $20 \%$ of the total intensity.

When a temporal survey was carried out in Lake Vilar a shift from crenarchaeota to thermoplasmalesrelated sequences was observed from winter to summer (Fig. 5). Crenarchaeota accounted for up to $80 \%$ of the total band intensity in February and progressively decreased to $10 \%$ in June. In parallel, thermoplasmales-related sequences increased from $<10 \%$ in February up to $60 \%$ in June. The methanogen contribution was largest in spring (around $45 \%$ of the total band intensity) but similar percentages were measured in winter and summer (between 5 and 10\%). Only 1 sequence of crenarchaeota was recovered from Lake Vilar (VIARC-2). On the other hand, 2 closely related sequences within the thermoplasmales cluster (VIARC-1 and VIARC-5, 99\% similarity in 16S rDNA between them) and 2 of methanogens (VIARC-3 and VIARC-4, 98\% similarity) were recovered from Lake Vilar. These sequences showed temporal changes in their respective band intensities (Fig. 6). 


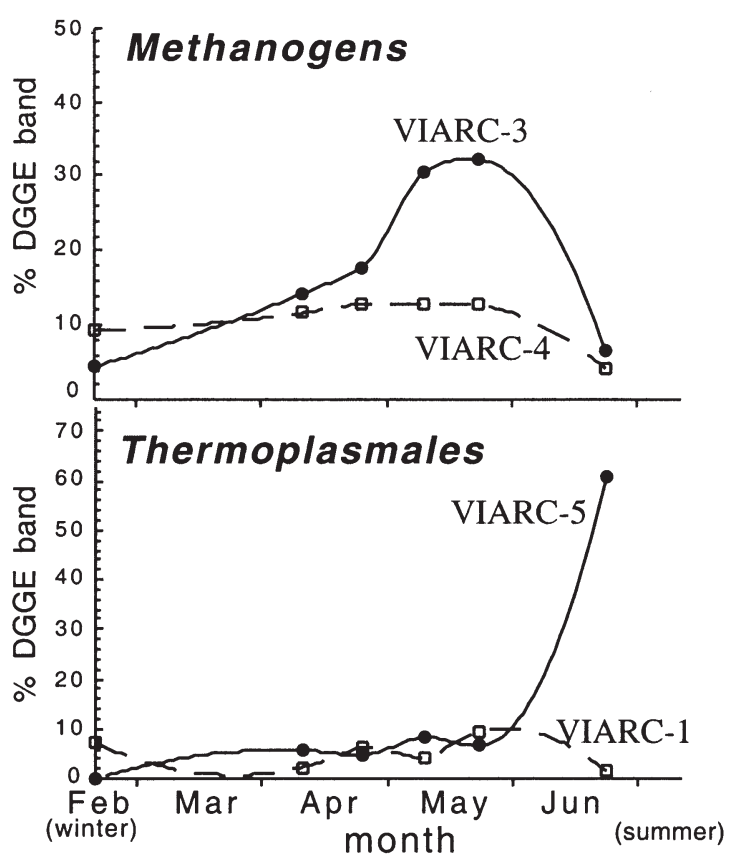

Fig. 6. Changes in the relative abundance of closely related sequences ( $\geq 98 \%$ similarity in $16 \mathrm{~S}$ rDNA sequence) detected in the temporal study of Lake Vilar. Quantitative data were obtained from the gel in Fig. 2

\section{DISCUSSION}

Up to now, freshwater planktonic culturable Archaea were restricted to methanogens and sulfurmetabolizing thermophiles. Archaea inhabiting sulfurous environments had been restricted mostly to crenarchaeotes with thermophilic and acidophilic metabolisms (Brock 1997, Huber et al. 1998, Vásquez et al. 1999). Methanogens have also been detected coexisting with sulfate reducers in sulfurous environments although at very low rates of activity (Senior et al. 1982) and were expected not to be very abundant in such systems because sulfate-reducing bacteria are better competitors for available acetate and $\mathrm{H}_{2}$ (Abram \& Nedwell 1978). Recently, a planktonic crenarchaeota-related 16S rDNA sequence was obtained from a Norwegian meromictic lake (Lake Sælenvannet; $150 \mu \mathrm{M}$ sulfide, salinity $2 \%$ ) and methanogens were also present (Øvreås et al. 1997). Methanogens and thermoplasmales-related sequences have also been detected in the sulfide-rich water layers of the saline Solar Lake (1 mM sulfide; salinity 19\%) (Cytryn et al. 2000). Obviously, members of these groups are able to thrive in a wide range of environments and are not limited to the extremophiles known from cultures.

In the present work we have compared archaeal assemblages from several anaerobic, sulfide-rich hypolimnia. In situ conditions in these habitats match nei- ther with the physiological demands of cultured archaeal strains nor with the environments from where clones deposited in databases were obtained. Therefore, these systems are potential habitats for unknown groups of Archaea. For this comparison we have used a fingerprinting technique (DGGE) and sequence analysis of the resulting bands. The small number of published studies using DGGE separation of $16 \mathrm{~S}$ rDNA PCR products of Archaea reflects that this separation has been difficult to perform. Most of these publications show DGGE profiles characterized by highly complex and mostly diffuse bands. In several cases, a previous nested PCR step was introduced (e.g., Øvreås et al. 1997) that might increase the potential biases introduced by PCR. We have described a primer set and PCR conditions that yielded successful fingerprints with mostly sharp bands in the gel (Casamayor et al. 2000b). The PCR products were obtained directly from the original DNA and allowed us to carry out a semi-quantitative approximation. In addition, the length of the PCR product (600 bp) allowed more reliable identification of the sequences than using shorter 16S rDNA fragments for comparison in databases. A recent work targeting the same 16S rDNA region (Cytryn et al. 2000) reported nonspecific amplification using a similar primer set when annealing temperature decreased to $52^{\circ} \mathrm{C}$. On the contrary, our results showed that all the sequences we recovered from the fingerprints belonged to Archaea. Some of the bands excised from our gel, however, did not yield useable sequence data. This difficulty, intrinsic to DGGE, may be related to the presence of different sequences in the same DGGE band or to the fact that weak bands may not have enough template DNA for their reamplification. A more detailed discussion on potentials and limitations of DGGE has been previously published (Casamayor et al. 2000b).

Archaeal DGGE fingerprints are considerably heterogeneous among systems and differences within each lake were smaller than those between lakes. A temporal survey indicated, however, strong changes in time for the archaeal assemblage in Lake Vilar. Therefore, these assemblages appear to be different among lakes, but also summer and winter populations can be different within a lake. This and the identity of the main populations were confirmed after sequencing of the DGGE bands. As expected, the archaeal sequences retrieved did not share close similarity with any cultured organisms. The sequences recovered belonged to 3 different groups. First, the methanogens that we recovered were closely related to a methanogenic endosymbiont of the anaerobic ciliate Plagiopyla. This is a well-known symbiosis (Wagener et al. 1990, Fenchel \& Finlay 1991) and in our study sites anaerobic ciliates such as Plagiopyla and Metopus were also seen by epifluorescence microscopy carrying endosymbiontic 
methanogens (Massana \& Pedrós-Alió 1994). Second, we found that the previously described crenarchaeotal sequence VIARC-2 (Casamayor et al. 2000b) was present in Lake Vilar throughout the temporal study. And, third, the phylogenetic affiliation showed a new lineage of organisms within the thermoplasmales and relatives group that contained only our sequences from karstic lakes (Lake Vilar, Lake Banyoles, Lake El Tobar and Lake La Cruz). This lineage is included in a bigger cluster containing sequences from freshwater environments (clones from sediments and plankton).

The same fingerprinting and identical sequences (BANARC-5, -6 and -7) were obtained from the 3 basins of Lake Banyoles (B-III, B-IV and B-VI). This is not surprising because all 3 basins are interconnected within this multibasin lake (Casamitjana \& Roget 1993). Interestingly, sequences from Lake Banyoles and Lake Vilar, which were only $10 \mathrm{~m}$ apart, were not the same. All these sequences were distantly related to sequences CIARC-3 and CIARC-2 obtained from Lake Cisó (1 km away from the former). These results are in line with previous results, suggesting that anaerobic hypolimnia of stratified lakes may act as islands in an aerobic world for anaerobic microorganisms (Casamayor et al. 2000b). We cannot exclude, however, that different limnological conditions for each lake may select different microbial assemblages.

Recent reports show that the group of thermoplasmales and relatives is more widely spread than previously thought and can be found in both marine and freshwater environments (DeLong 1998, Van der Maarel et al. 1998, Bowman et al. 2000, Jurgens et al. 2000, Massana et al. 2000). We found sequences related to the thermoplasmales and relatives in 7 out of 9 study sites, but we cannot discount that they were also present in the high percentage of undetermined sequences from Lake Cadagno and the El Cibollar coastal lagoon. Therefore, they appear to be a widespread lineage. The sequences we retrieved were not related to clones from marine environments and in some cases were close to sequences from lake sediments. Unfortunately, these organisms have not been recovered in pure culture and phenotypic properties cannot be inferred either, due to their distant genotypic relation with cultured archaea. Therefore, their ecological significance, biochemistry, physiology and impact on biogeochemical cycles remain unknown. Some of the archaeal sequences are closely related to endosymbionts and we cannot rule out that some others also correspond to endosymbiontic microorganisms. It is also possible that new anaerobic metabolisms or microbial interactions are involved, as was shown recently for the anaerobic oxidation of ammonium and methane (Jetten et al. 1998, Strous et al. 1999, Boetius et al. 2000) and the association with metazoan species (Preston et al. 1996, Van der Maarel et al. 1998).
Using the relative band intensity as an estimate of abundance, we found a striking dominance of thermoplasmales-related sequences within the archaeal assemblage of sulfurous lakes, especially in the Banyoles karstic area, and a temporal change in the abundance of populations. These changes where higher than the methodological error of $4 \%$ intensity (e.g., $70 \%$ range of variability for crenarchaeota and $50 \%$ for thermoplasmales; see Fig. 5). We were cautious in the number of PCR cycles run to avoid the 'plateau' phase and in using the same amount of template in each reaction. The samples that we compared were run in the same PCR run and analyzed in the same DGGE gel. If there was any PCR bias, it should have been the same in all lanes. Therefore, comparison among these samples is valid. In addition, throughout the seasonal study, gradual changes were seen and were not a random distribution of the intensity of the band for each population, adding further credibility to the changes observed. Moreover, we and others have published acceptable correlation between quantitative information obtained by microscopy and by DGGE (Casamayor et al. 2000b and references therein). Thus, although not free of limitations, signal intensity of DGGE bands obtained after ethidium-bromide staining is a useful tool to calculate relative percentages of the different groups. Obviously, absolute quantitative data on archaeal abundance require the use of other techniques.

Our study found qualitative and quantitative temporal changes in the archaeal assemblage of a lake, and we were able to identify the populations involved by DGGE and sequencing. Temporal changes in archaeal assemblages were recently described affecting morphology, abundance and identity of archaeal assemblages in several systems. Thus, successive peaks of 2 archaeal morphotypes were observed during autumn in a high mountain lake by fluorescence in situ hybridization (FISH) (Pernthaler et al. 1998). A maximum of $5 \%$ of all DAPI-stained cells (equivalent to around $1.7 \times 10^{5}$ archaeal cells $\mathrm{ml}^{-1}$ ) hybridized with the general archaeal probe ARCH915 in this lake but archaeal populations were hardly present thereafter. In Antarctic coastal waters, a strong seasonality of archaeal rRNA concentrations has been reported, with the highest values occurring during the austral winter and early spring (Massana et al. 1998, Murray et al. 1998). Marine group I (crenarchaeota-affiliated) was shown to be more abundant in Antarctic coastal waters in late winter and early spring, whereas the marine group II (thermoplasmales-affiliated) was a minor component but peaked in abundance in summer and early autumn (Murray et al. 1998). Intriguingly, this temporal partitioning of the system between crenarchaeota and thermoplasmales-related micro- 
organisms matches what we have found in a karstic lake. The environmental factors responsible for these changes in time, however, remain unknown.

Our results indicate that the genetic diversity of Archaea is relatively large in non-thermophilic, sulfurous environments. We were able to identify shifts in sequences at the microdiversity scale (more than $97 \%$ similarity in 16S rDNA) after sequencing DGGE bands. Several investigators have indicated that such small differences in 16S rRNA genes may belong to closely related but ecologically different populations (Fuhrman \& Campbell 1998, Moore et al. 1998). The abundance of these Archaea remain to be determined but these data suggest that they are novel types of organisms that may be widely distributed and contribute to the anaerobic biogeochemical cycles of karstic lakes and coastal lagoons. The vertical distribution (accumulating in sulfide-rich layers) and the temporal dynamics indicate that these archaeal assemblages are autochthonous. The challenge now is to determine the physiological capabilities and environmental roles of these uncultured but ecologically relevant Archaea.

Acknowledgements. This work was financed by the Max Planck Society in Germany, by DGICyT grant number PB950222 from the Spanish Ministerio de Educación y Cultura and by project MIDAS (Microbial Diversity in Aquatic Systems, MAS3-CT97-0154) from the European Union. We thank R. Amann for his generous and continuous support and L. Bañeras, C. M. Borrego, R. Rosselló-Mora and R. Bachofen for sampling facilities and sharing field data. H. Schäfer is thanked for optimization of DGGE conditions and R. Massana for helpful comments on the manuscript. We also thank 3 anonymous reviewers for comments and suggestions. E.O.C. benefited from the exchange program between CSIC and the Max Planck Society.

\section{LITERATURE CITED}

Abram JW, Nedwell DB (1978) Inhibition of methanogenesis by sulfate reducing bacteria competing for transferred hydrogen. Arch Microbiol 117:89-92

Altschul SF, Gish W, Miller W, Myers EW, Lipman DJ (1990) Basic local alignment search tool. J Mol Biol 215:403-410

Barns SM, Delwiche CF, Palmer JD, Pace NR (1996) Perspectives on archeal diversity, thermophily and monophyly from environmental rRNA sequences. Proc Natl Acad Sci USA 93:9188-9193

Boetius A, Ravenschlag K, Schubert CJ, Rickert D, Widdel F, Gieseke A, Amann R, Jorgensen BB, Witte U, Pfannkuche O (2000) A marine microbial consortium apparently mediating anaerobic oxidation of methane. Nature 407: 623-626

Borrego CM, Garcia Gil LJ, Vila X, Cristina XP, Figueras JB, Abellà CA (1997) Distribution of bacteriochlorophyll homologs in natural populations of brown-colored phototrophic sulfur bacteria. FEMS Microbiol Ecol 24:301-309

Bosshard PP, Santini Y, Gruter D, Stettler R, Bachofen R (2000) Bacterial diversity and community composition in the chemocline of the meromictic alpine Lake Cadagno as revealed by $16 \mathrm{~S}$ rDNA analysis. FEMS Microbiol Ecol 31: 173-182

Bowman JP, Rea SM, McCammon SA, McMeekin TA (2000) Diversity and community structure within anoxic sediment from marine salinity meromictic lakes and a coastal meromictic marine basin, Vestfold Hills, Eastern Antarctica. Environ Microbiol 2:227-237

Brock TD (1997) Prokaryotic diversity: Archaea. In: Madigan MT, Martinko JM, Parker J (eds) Biology of microorganisms, 8th edn. Prentice Hall Inc, Englewood Cliffs, NJ

Buckley DH, Graber JR, Schmidt TM (1998) Phylogenetic analysis of nonthermophilic members of the kingdom Crenarchaeota and their diversity and abundance in soils. Appl Environ Microbiol 64:4333-4339

Casamayor EO, Núñez-Cardona MT, Calderón-Paz JI, Mas J, Pedrós-Alió C (2000a) Comparison of pure cultures and natural assemblages of planktonic photosynthetic sulfur bacteria by low molecular mass RNA fingerprinting. FEMS Microbiol Ecol 32:25-34

Casamayor EO, Schafer H, Bañeras L, Pedrós-Alió C, Muyzer G (2000b) Identification of and spatio-temporal differences between microbial assemblages from two neighboring sulfurous lakes: comparison by microscopy and denaturing gradient gel electrophoresis. Appl Environ Microbiol 66:499-508

Casamitjana C, Roget E (1993) Resuspension of sediment by focused groundwater in Lake Banyoles. Limnol Oceanogr 38:643-656

Crump BC, Baross, JA (2000) Archaeaplankton in the Columbia River, its estuary and the adjacent coastal ocean, USA. FEMS Microbiol Ecol 31:231-239

Cytryn E, Minz D, Oremland RS, Cohen Y (2000) Distribution and diversity of archaea corresponding to the limnological cycle of a hypersaline stratified lake (Solar Lake, Sinai, Egypt). Appl Environ Microbiol 66:3269-3276

DeLong EF (1992) Archaea in coastal marine environments. Proc Natl Acad Sci USA 89:5685-5689

DeLong EF (1998) Everything in moderation: archaea as 'nonextremophiles'. Curr Opin Genet Dev 8:649-654

DeLong EF, Wu KY, Prezelin BB, Jovine RV (1994) High abundance of Archaea in Antarctic marine picoplankton. Nature 371:695-697

Fenchel T, Finlay BJ (1991) Synchronous division of an endosymbiotic methanogenic bacterium in the anaerobic ciliate Plagiopyla frontata Kahl. J Protozool 38:22-28

Fritz M, Bachofen R (2000) Volatile organic sulfur compounds in a meromictic Alpine lake. Acta Hydrochim Hydrobiol 28:185-192

Fuhrman JA, Campbell L (1998) Microbial microdiversity. Nature 393:410-411

Fuhrman JA, McCallum K, Davis AA (1992) Novel major archaebacterial group from marine plankton. Nature 356: 148-149

Garcia-Gil LJ, Casamitjana X, Abellà CA (1996) Comparative study of two meromictic basins of Lake Banyoles (Spain) with sulphur phototrophic bacteria. Hydrobiologia 319: 203-211

Garcia-Gil LJ, Vicente E, Camacho A, Borrego CM, Vila X, Cristina XP, Rodriguez-Gonzalez J (1999) Vertical distribution of photosynthetic sulfur bacteria linked to saline gradients in Lake El Tobar (Cuenca, Spain). Aquat Microb Ecol 20:299-303

Golterman HL, Clymo RS, Ohnstad MAM (1978) Methods for physical and chemical analysis of fresh waters. IBP Handbook No. 8. Blackwell Scientific, Oxford

Guerrero R, Pedrós-Alió C, Esteve I, Mas J (1987) Communities of phototrophic sulfur bacteria in lakes of the Spanish 
Mediterranean region. Act Acad Aboensis 47:125-151

Hershberger KL, Barns SM, Reysenbach AL, Dawson SC, Pace NR (1996) Wide diversity of Crenarchaeota. Nature 384:420

Huber R, Dyba D, Huber H, Burggraf S, Rachel R (1998) Sulfur-inhibited Thermosphaera aggregans sp. nov., a new genus of hyperthermophilic archaea isolated after its prediction from environmentally derived $16 \mathrm{~S}$ rRNA sequences. Int J Syst Bacteriol 48:31-38

Jetten MSM, Strous M, van de Pas-Schoonen KT, Schalk J, van Dongen U, van de Graaf AA, Logemann S, Muyzer G, van Loosdrecht MCM, Kuenen JG (1998) The anaerobic oxidation of ammonium. FEMS Microbiol Rev 22:421-437

Jurgens G, Lindstrom K, Saano A (1997) Novel group within the kingdom Crenarchaeota from boreal forest soil. Appl Environ Microbiol 63:803-805

Jurgens G, Glöckner FO, Amann R, Saano A, Montonen L, Likolammi M, Münster U (2000) Identification of novel Archaea in bacterioplankton of a boreal forest lake by phylogenetic analysis and fluorescent in situ hybridization. FEMS Microbiol Ecol 34:45-56

Karner MB, DeLong EF, Karl DM (2001) Archaeal dominance in the mesopelagic zone of the Pacific Ocean. Nature 409: 507-510

Massana R, Pedrós-Alió C (1994) Role of anaerobic ciliates in planktonic food webs: abundance, feeding, and impact on bacteria in the field. Appl Environ Microbiol 60: 1325-1334

Massana R, Taylor LJ, Murray AE, Wu KY, Jeffrey WH, DeLong EF (1998) Vertical distribution and temporal variation of marine planktonic Archaea in the Gerlache Strait, Antarctica, during early spring. Limnol Oceanogr 43:607-617

Massana R, DeLong EF, Pedrós-Alió C (2000) A few cosmopolitan phylotypes dominate planktonic archaeal assemblages in widely different oceanic provinces. Appl Environ Microbiol 66:1777-1787

Miracle MR, Vicente E, Pedrós-Alió C (1992) Biological studies in Spanish meromictic and stratified karstic lakes. Limnetica 8:59-77

Moore LR, Rocap G, Chisholm SW (1998) Physiology and molecular phylogeny of coexisting Prochlorococcus ecotypes. Nature 393:464-467

Moyà G, Ramon G, Martínez-Taberner A, Forteza V, Picó C, Ponsell C, Rosselló R, Soberats MA (1987) Limnology of a meromictic coastal lagoon: l'estany del Cibollar (Majorca, Balearic Islands). Limnetica 3:255-262

Murray AE, Preston CM, Massana R, Taylor LT, Blakis A, Wu K, DeLong EF (1998) Seasonal and spatial variability of bacterial and archaeal assemblages in the coastal waters near Anvers Island, Antarctica. Appl Environ Microbiol 64:2585-2595

Murray AE, Blakis A, Massana R, Strawzewski S, Passow U, Alldredge A, DeLong EF (1999) A time series assessment of planktonic archaeal variability in the Santa Barbara Channel. Aquat Microb Ecol 20:129-145

Muyzer G, Brinkhoff T, Nübel U, Santegoeds C, Schäfer H, Wawer C (1998) Denaturing gradient gel electrophoresis (DGGE) in microbial ecology. In: Akkermans ADL, van Elsas JD, de Bruijn FJ (eds) Molecular microbial ecology manual. Kluwer Academic, Dordrecht, p 1-27

Ouverney CC, Fuhrman JA (2000) Marine planktonic Archaea take up amino acids. Appl Environ Microbiol 66: 4829-4833

Øvreås L, Forney L, Daae FL, Torsvik V (1997) Distribution of bacterioplankton in meromictic Lake Saelenvannet, as determined by denaturing gradient gel electrophoresis of

Editorial responsibility: Dittmar Hahn,

Newark, New Jersey, USA
PCR-amplified gene fragments coding for 16S rRNA. Appl Environ Microbiol 63:3367-3373

Pace NR (1997) A molecular view of microbial diversity and the biosphere. Science 276:734-740

Pedrós-Alió C, Guerrero R (1993) Microbial ecology in Lake Cisó. Adv Microb Ecol 13:155-209

Pernthaler J, Glöckner FO, Unterholzner S, Alfreider A, Psenner R, Amann R (1998) Seasonal community and population dynamics of pelagic bacteria and archaea in a high mountain lake. Appl Environ Microbiol 64:4299-4306

Porter KG, Feig YS (1980) The use of DAPI for identifying and counting aquatic microflora. Limnol Oceanogr 25:943-948

Preston CM, Wu KY, Molinski TF, DeLong EF (1996) A psychrophilic crenarchaeon inhabits a marine sponge: Cenarchaeum symbiosum gen. nov., sp. nov. Proc Natl Acad Sci USA 93:6241-6246

Putschew A, Scholzbottcher BM, Rullkotter J (1996) Early diagenesis of organic matter and related sulphur incorporation in surface sediments of meromictic Lake Cadagno in the Swiss Alps. Org Geochem 25:379-390

Raskin L, Stromley JM, Rittmann BE, Stahl DA (1994) Groupspecific 16S rRNA hybridization probes to describe natural communities of methanogens. Appl Environ Microbiol 60: 1232-1240

Schanz F, Fischer-Romero C, Bachofen R (1998) Photosynthetic production and photoadaptation of phototrophic sulfur bacteria in Lake Cadagno (Switzerland). Limnol Oceanogr 43:1262-1269

Senior E, Lindström EB, Banat IM, Nedwell DB (1982) Sulfate reduction and methanogenesis in the sediment of a saltmarsh on the east coast of the United Kingdom. Appl Environ Microbiol 43:987-996

Stahl DA, Amann RI (1991) Development and application of nucleic acid probes. In: Stackebrandt E, Goodfellow M (eds) Nucleic acid techniques in bacterial systematics. Wiley, New York, p 205-248

Stein JL, Simon MI (1996) Archaeal ubiquity. Proc Natl Acad Sci USA 93:6228-6230

Strous M, Fuerst JA, Kramer EHM, Logemann S, Muyzer G, van de Pas-Schoonen KT, Webb R, Kuenen JG, Jetten MSM (1999) Missing lithotroph identified as new planctomycete. Nature 400:446-449

Tonolla M, Demarta A, Peduzzi S, Hahn D, Peduzzi R (2000) In situ analysis of sulfate-reducing bacteria related to Desulfocapsa thiozymogenes in the chemocline of meromictic Lake Cadagno (Switzerland). Appl Environ Microbiol 66:820-824

Van der Maarel MJEC, Artz RRE, Haanstra R, Forney LJ (1998) Association of marine archaea with the digestive tracts of two marine fish species. Appl Environ Microbiol 64:2894-2898

Vásquez M, Moore ERB, Espejo RT (1999) Detection by polymerase chain reaction amplification and sequencing of an archaeon in a commercial-scale copper bioleaching plant. FEMS Microbiol Lett 173:183-187

Wagener S, Schulz S, Hanselmann K (1990) Abundance and distribution of anaerobic protozoa and their contribution to methane production in Lake Cadagno, Switzerland. FEMS Microbiol Ecol 74:39-48

Woese CR (2000) Interpreting the universal phylogenetic tree. Proc Natl Acad Sci USA 97:8392-8396

Woese CR, Kandler O, Wheelis ML (1990) Towards a natural system of organisms: proposal for the domains Archaea, Bacteria, and Eucarya. Proc Natl Acad Sci USA 87: $4576-4579$

Submitted: March 21, 2001; Accepted: June 13, 2001

Proofs received from author(s): September 7, 2001 